\title{
APROXIMACE EVAKUAČNÍ KŘIVKY METODOU POLYNOMICKÉ REGRESE
}

\section{APPROXIMATION OF EVACUATION CURVE BY THE POLYNOMIC REGRESSION METHOD}

\author{
Ondřej Uhlík*,1, Lucie Dobiášová ${ }^{1}$, Martina Kratochvílová ${ }^{1}$
}

"ondrej.uhlik@vut.cz

${ }^{1}$ Vysoké učení technické v Brně, Fakulta stavební, Ústav automatizace inženýrských úloh a informatiky, Veveři 331/95, 60200 Brno, Česká republika

\begin{abstract}
Abstrakt
Predikce průběhu evakuačního procesu v čase mimořádné události je klíčová pro následnou efektivní koordinaci evakuace a zásah složek IZS. Mikroskopické simulační nástroje jsou v současnosti nejpokročilejší metodou modelování evakuace, nicméně jejich využití v provozní fázi stavby je vzhledem k výpočetnímu času simulací a dynamickým vstupním datům neefektivní. Jedním z výstupů simulací je evakuační křivka. V článku je navrženo zjednodušení křivky aproximační metodou polynomické regrese, které demonstruje na základní úloze. Koeficienty polynomu mohou být využity při sestavování trénovací množiny modelu strojového učení pro predikci evakuačních křivek v reálném čase.
\end{abstract}

\section{Klíčová slova}

Modelování evakuace, simulace, evakuační křivka, aproximace, polynomická regrese

\begin{abstract}
Prediction of the evacuation process at the time of the emergency is crucial for the subsequent effective coordination of the evacuation and the intervention of the rescue units. Microscopic simulation tools are currently the most advanced method of evacuation modelling, however, their use in the operational phase of construction is inefficient due to the computational time of the simulations and dynamic input data. One of the outputs of the simulations is the evacuation curve. The paper proposes a simplification of the curve by the approximation method of polynomial regression, which demonstrates on basic evacuation scenario. The polynomial coefficients can be used to compile a training set of a machine learning model to predict real-time evacuation curves.
\end{abstract}

Key words

Evacuation modelling, simulation, evacuation curve, approximation, polynomial regression

\section{1 ÚVOD}

Modelování evakuačního procesu je zásadní pro posouzení bezpečnosti návrhu budov již v jejich projektové fázi. Současnou výzvou v této problematice je využití evakuačních modelů v provozní fázi stavby. Okamžitá predikce evakuačního procesu při vzniku mimořádné události (např. požáru, teroristického útoku apod.) na základě aktuálních podmínek v objektu (zejména počtu osob) může být klíčová pro efektivní reakci managementu objektu a složek IZS na tuto mimořádnou událost. Mezi tyto predikce lze zařadit např. předpokládané zatížení únikových východů osobami, celkový evakuační čas nebo vývoj počtu evakuovaných osob v čase (tzv. evakuační křivka).

Mezi nejpokročilejší nástroje pro modelování evakuace staveb s vysokou obsazeností (např. nádražní budovy, stanice metra, sportovní stadiony apod.) patří mikroskopické modely pohybu osob. Využití mikroskopických simulací v čase mimořádné události je v současnosti neefektivní zejména $\mathrm{z}$ důvodu dynamických vstupních dat ovlivňujících průběh evakuace (počet osob v objektu, jejich pozice, genderové a věkové rozložení aj.) a výpočetního času simulací, který může dosahovat desítek minut až hodin v závislosti na komplexnosti objektu a dostupném hardware.

Metody strojového učení, které v posledních letech pronikají do stále více oblastí pracujících s daty, mají potenciál predikovat zmíněné výstupy simulací v reálném čase. V článku je zkoumána možnost aproximace evakuační křivky pro následnou predikci jejího tvaru. Cílem aproximace je dostatečně přesná charakteristika 
evakuační křivky s odpovídajícím počtem koeficientů polynomu. Koeficienty takto získaného polynomu je možné dále použít jako trénovací množinu modelu strojového učení (např. umělých neuronových sítí) pro predikci tvaru křivky v reálném čase. Tento postup je ověřen na základní úloze evakuace místnosti.

\section{POPIS SOUČASNÉHO STAVU}

Jako standardní př́istupy k modelování evakuace lze uvést metodické postupy, inženýrské výpočty, evakuační cvičení a simulace [1]. Cílem těchto metod je predikovat evakuační proces v maximální možné míře detailu pro posouzení bezpečnosti návrhu stavby a sestavení evakuačního plánu. Na území ČR se pro predikci evakuačního procesu primárně užívají požární normy ČSN [2], [3], [4] a v posledních letech se začínají využít mikroskopické simulační nástroje [5]. Jejich hlavní předností je možnost komplexní analýzy libovolného počtu scénářů mimořádné události (nejen požáru, ale např́klad i teroristického útoku) již v projektové fázi výstavby se zohledněním fyzikálních a behaviorálních jevů, ke kterým při evakuaci dochází. Zároveň umožňují zohlednit antropogenní faktor, např. v podobě zablokování únikové cesty agresorem. Tímto převyšují ostatní zmíněné metody. Jedním z hlavních kritérií evakuačního procesu je celkový evakuační čas, tedy doba, která je zapotřebí pro evakuaci všech osob v objektu. Tato veličina je interpretována na základě statistiky (v př́padě užití stochastických modelů), teplotní mapy nebo grafu popisujícím evakuační křivku. T. Rinne a kol. analyzoval celkem 18 evakuačních procesů v různých typologiích objektů a pro každý stanovil evakuační křrivku [6].

Algoritmy hluboké učení se stále více využívají v oblasti dynamiky pohybu chodců. Jejich nasazení proběhlo např. v rámci monitorování pěší dopravy v reálném čase [7], predikce trajektorie pohybu chodců [8], [9], [10], predikce rychlosti a časových odstupů na základě aktuální pozice chodců [11], řešení kolizí při interakci robotů s chodci [12] nebo zkoumání vztahů veličin fundamentálního diagramu [13].

\section{POUŽITÉ METODY}

\section{Mikroskopický evakuační model}

Pro demonstraci aproximace evakuační křivky byl nasazen agentní mikroskopický model Pathfinder [14] v němž byl sestaven triviální simulační experiment evakuace obdélníkové místnosti $(40$ x $7 \mathrm{~m}) \mathrm{s}$ jedním východem na volné prostranství o šířce $2,5 \mathrm{~m}$. V levé části místnosti je umístěno 150 osob (agentů). Na Obr. 1 je znázorněno log-normální rozdělení doby před pohybem a normální rozdělení rychlosti pohybu. Jedná se o hlavní charakteristiky osob při posuzování evakuace. Oba tyto parametry mají zásadní vliv na průběh evakuace, a tedy i tvar evakuační křivky. Parametry obou rozdělení jsou popsány v Tab. 1. Počet simulací byl stanoven na 50 dle Ronchiho metody zabývající se analýzou konvergence [15]. Z těchto 50 simulací byl následně spočítán průměrný evakuační čas pro všechny osoby a vykreslena evakuační křivka (viz Obr. 4).

Tab. 1 Parametry mikroskopického modelu pohybu osob.

\begin{tabular}{ccccc}
\hline & $\mathbf{5 \%}$ & $\mathbf{9 5} \mathbf{\%}$ & $\boldsymbol{\mu}$ & $\boldsymbol{\sigma}$ \\
\hline Rychlost pohybu $[\mathrm{m} / \mathrm{s}]$ & 0,73 & 1,95 & 1,34 & 0,37 \\
Doba před pohybem $[\mathrm{s}]$ & 14 & 74 & 35,9 & 18,3 \\
\hline
\end{tabular}
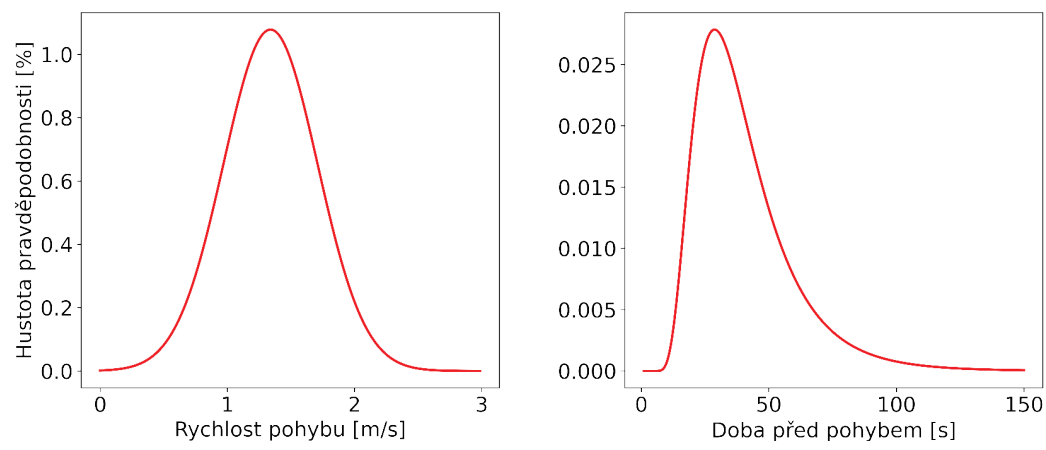

Obr. 1 Normální rozdělení rychlosti pohybu (vlevo) a log-normální rozdělení doby před pohybem (vpravo). 


\section{Polynomická regrese}

Cílem metody je najít polynom, který dostatečně přesně aproximuje body evakuační křivky. Koeficienty polynomu jsou hledány metodou nejmenších čtverců. Ve většině př́ipadů platí, že čím vyšší stupeň polynomu, tím přesnější aproximace, ale také větší pravděpodobnost natrénování šumu, a ne skutečného trendu.

V návaznosti na 3.1, kde je popsán obecný tvar evakuační křivky, lze předpokládat možnost aproximace této křivky polynomem k-tého stupně, jehož koeficienty lze následně použít jako vstupní data pro model strojového učení. Podoba trénovací množiny pro následnou predikci tvaru evakuační křivky je zásadní zejména pro její nutný rozsah. Vstupní proměnné by mohly zahrnovat např. počet osob, jejich rozmístění, genderové složení aj. Výstupní proměnnou by pak byla evakuační křivka. Pokud by byla křivka popsána vektorem jejích datových bodů, byla by zapotřebí velmi rozsáhlá trénovací množina i pro triviální úlohy. Z tohoto důvodu se polynomická regrese jeví jako optimální metoda redukce počtu výstupních proměnných na počet koeficientů polynomu. Optimální stupeň polynomu je potřeba stanovit pro danou úlohu metodou kř́žové validace a přesnost vyhodnotit pomocí vhodné metriky - např. analýzy reziduí stanovením střední kvadratické chyby (Root Mean Square Error - RMSE). V rámci simulačního experimentu byl pro křížovou validaci využit iterativní algoritmus $k$-fold, který rozdělí datovou sadu na $k$ podmnožin, přičemž v každé podmnožině jsou pro testování zvolena jiná data. Standardně se použivá rozdělení datové sady na 10 podmnožin, což bylo užito i v rámci této práce.

\section{VÝSLEDKY}

\section{Obecný tvar evakuační křivky}

Je potřeba konstatovat, že tvar evakuační křivky bude unikátní pro každý evakuační proces a je silně závislý na daném scénáři mimořádné události. Při bližší analýze evakuačních křivek v publikaci [6], lze však pozorovat minimálně 3 obecné fáze vymezené v čase, kdy je každá z nich zastoupena ve větší či menší míře. Fáze obecné evakuační křivky jsou demonstrovány pomocí funkce arctg na Obr. 2. Na každou fázi má vliv řada faktorů, z nichž budou jmenovány některé významné.

- Fáze A. Tato počáteční fáze je charakteristická zejména dobou před pohybem (tedy časem ohraničeným rozpoznáním nebezpečí a zahájením evakuace, který může dosahovat i několika minut [16]). Zároveň je v této fázi započítán čas, který osoby stráví na únikových cestách v objektu. Vlivem těchto faktorů dosáhne v této fázi únikových východů minoritní část evakuovaných osob.

- $\quad$ Fáze B. V této fázi majoritní část evakuovaných osob již zahájila pohyb směrem k únikovým východům a křivka má spíše lineární trend v závislosti na propustnosti jednotlivých únikových východů dané jejich efektivní šířkou. V této části může dojít ke změně sklonu křivky vyvolané postupným snižováním počtu využívaných únikových východů.

- $\quad$ Fáze C. Fáze, ve které je majoritní část osob již evakuována a dochází k evakuaci osob jejichž doba před pohybem nebo rychlost pohybu (popř. kombinace obojího) se pohybují v extrémních hodnotách jednotlivých distribucí. V praxi se může jednat o osoby s omezenou schopností pohybu, jiným způsobem handicapované osoby, nebo jednotlivce, kteří nezaznamenali či zanedbali př́íkaz k evakuaci. Zároveň se v této fázi bude evakuovat personál, který evakuaci ř́ídil.

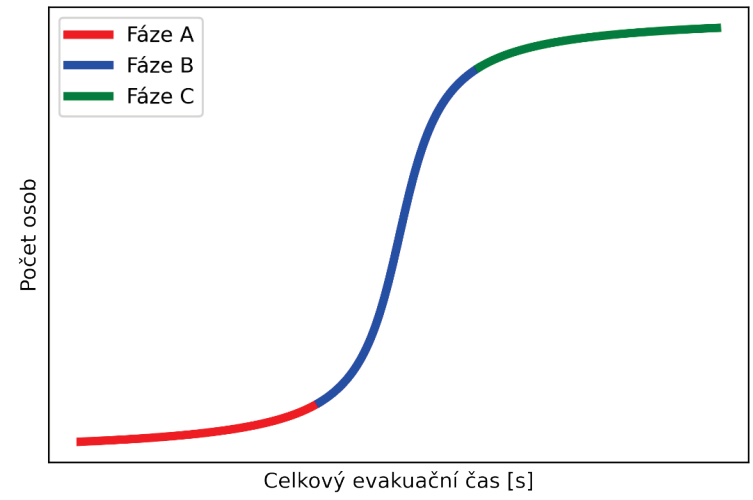

Obr. 2 Fáze evakuační křivky znázorněné na funkci $\operatorname{arctg}$. 


\section{Simulační experiment}

Na Obr. 3 je zobrazen simulační experiment ve třech fázích evakuačního procesu v časech simulace $0 \mathrm{~s}, 60 \mathrm{~s}$ a $90 \mathrm{~s}$. Vlivem distribuce doby před pohybem došlo u prvních osob k zahájení evakuace zhruba v čase 15 s. Poslední skupina osob zahájila evakuaci přibližně v čase $70 \mathrm{~s}$. Tento jev lze běžně při evakuaci očekávat a jak již bylo zmíněno, má zásadní vliv na tvar evakuační křivky.

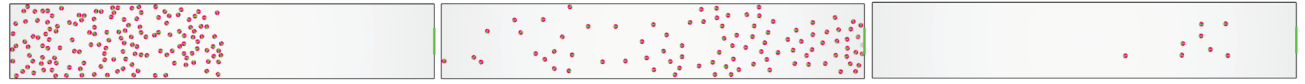

Obr. 3 Fáze evakuačního procesu triviální úlohy (vlevo: fáze A, uprostřed: fáze B, vpravo: fáze C).

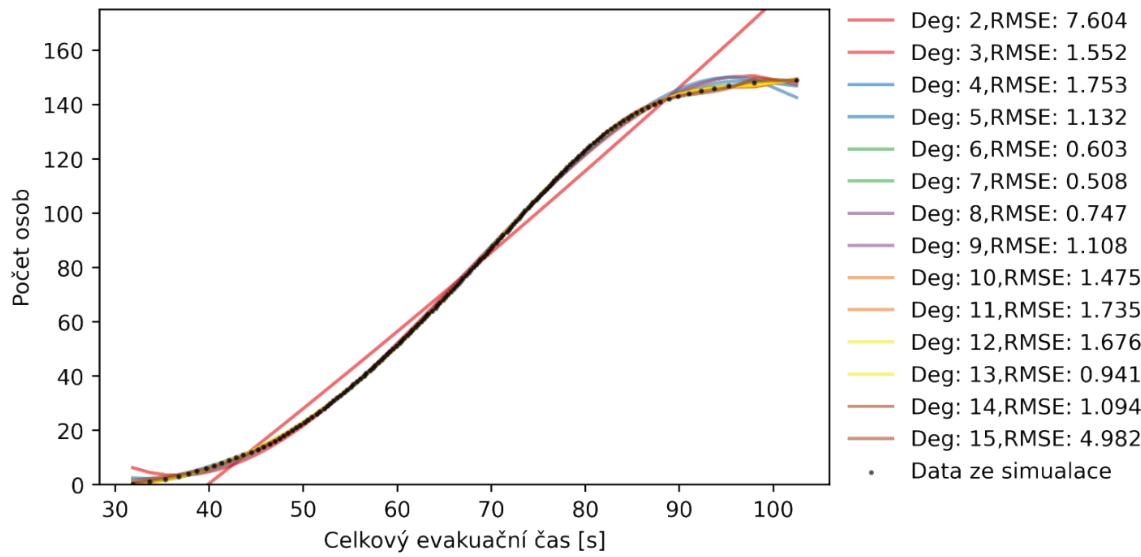

Obr. 4 Průměrná evakuační křivka simulačního experimentu a regresní křivky pro stupně polynomu 2-15.

\section{DISKUZE}

Na základě sady evakuačních křivek byly definovány 3 základní fáze vývoje počtu evakuovaných osob v čase, které se promítají do tvaru křivek. Průměrná evakuační křivka simulačního experimentu znázorněná na Obr. 4 odpovídá definovanému obecnému tvaru popsaném na Obr. 2. Polynomická regrese byla využita pro interpolaci dat v rozsahu daném minimálním a maximálním evakuačním časem (32 a 103 s). Extrapolace není pro tento typ úlohy potřebná a lze u ní očekávat výrazné snížení přesnosti. Přesnost regrese byla pro každý stupeň polynomu stanovena algoritmem kř́žové validace $k$-fold. Nejpřesnější aproximace bylo dosaženo polynomem 7 . stupně s hodnotu RMSE 0,508, nicméně z praktického hlediska by dostatečně přesnou aproximaci poskytl i polynom 3-6 stupně. Původních 150 bodů průměrné evakuační křivky bylo uvedeným postupem zjednodušeno na 3-7 koeficientů. U komplexnějších scénářủ evakuace lze očekávat vyšší stupeň polynomu pro dosažení podobné přesnosti. Zjednodušení evakuační křivky na takovýto počet koeficientů pro následnou predikci tvaru křivky umožňuje sestavit trénovací množinu v násobně menším rozsahu než v př́padě uvažování jednotlivých datových bodů křivky, což je z hlediska jednoduchosti architektury modelu strojového učení a nízké datové náročnosti velmi výhodné.

\section{ZÁVĚR}

Výstupy mikroskopických evakuačních modelů mají potenciál poskytovat validní informace o budoucím průběhu evakuace při mimořádné události. Jejich nasazení v reálném čase je však neefektivní vzhledem $\mathrm{k}$ dynamickým vstupním datům a výpočetnímu času simulací. Jedním z výstupů modelů je evakuační křivka, která podává informaci o počtu evakuovaných osob v čase.

Článek se zabýval obecným tvarem evakuační křivky, v níž definoval 3 základní fáze vývoje počtu evakuovaných osob v čase, které se promítají do tvaru křivky. Následně řešil možnost zjednodušení evakuační 
křivky aproximací metodou polynomické regrese pro následnou možnost predikce těchto křivek modelem strojového učení. Aproximace byla demonstrována na simulačním experimentu, na němž byl ověřen tvar evakuační křivky. Optimální stupeň polynomu byl stanoven kř́žovou validací a standardní metrikou RMSE. Metoda byla využita výhradně pro interpolaci dat v rozsahu daném minimálním a maximálním evakuačním časem. Na základě analýzy obecného tvaru evakuační křivky dle publikovaných dat, grafu průměrné evakuační křivky simulačního experimentu a výsledků polynomické regrese lze považovat tuto metodu za vhodnou pro tento typ úloh. Zjednodušení způsobené aproximací je v rozmezí rozptylu daného stochastickou povahou simulací použitého modelu a nesnižuje tedy spolehlivost interpretovaných dat. Tato práce tak nabízí nový přístup $\mathrm{k}$ přípravě trénovacích dat pro využití metod strojového učení v rámci modelování evakuace. $\mathrm{V}$ dalším návazném výzkumu by mělo dojít k samotnému testování predikce koeficientů polynomů metodami strojového učení a validaci těchto predikcí na datech z reálného experimentu evakuace.

\section{Poděkování}

Př́íspěvek byl vypracován v rámci řešení projektu fakultního specifického výzkumu č. FAST-J-21-7522 Evakuace provizorních nemocnic s využitím modelu evakuace.

\section{Použité zdroje}

[1] ROSENBAUM, Eric R., Steven M. V. GWYNNE, ed. Employing the Hydraulic Model in Assessing Emergency Movement. In: HURLEY, Morgan J. SFPE Handbook of Fire Protection Engineering. 5. New York: Springer, 2016, s. 2115-2151. ISBN 978-1-4939-2565-0.

[2] ČSN 730802 Požární bezpečnost staveb. Nevýrobní objekty. Praha: Úřad pro technickou normalizaci, metrologii a státní zkušebnictví, 2009.

[3] ČSN 730831 Požární bezpečnost staveb - Shromažd'ovací prostory. Praha: Úřad pro technickou normalizaci, metrologii a státní zkušebnictví, 2011.

[4] ČSN 730818. Požární bezpečnost staveb - Obsazení objektů osobami. 1997. Úřad pro technickou normalizaci metrologii a státní zkušebnictví.

[5] KULIGOWSKI, Erica D., Richard D. PEACOCK a Bryan L. HOSKINS. A Review of Building Evacuation Models. Technical Note (NIST TN) - 1680. Gaithersburg, MD: National Institute of Standards and Technology, 2010.

[6] RINNE, Tuomo, Kati TILLANDER a Peter GRONBERG. Data Collection and Analysis of Evacuation Situations: VTT Tiedotteita - Research Notes 2562. Helsinki: VTT Technical Research Centre of Finland, 2010. ISBN 978-951-38-7674-6.

[7] Pedestrian \& cyclist monitoring. DataFromSky [online]. [cit. 2021-11-26]. Dostupné z: https://datafromsky.com/pedestrian-cyclist-monitoring/

[8] ZAMBONI, Simone, Zekarias Tilahun KEFATO, Sarunas GIRDZIJAUSKAS a Christoffer NORÉN. Pedestrian trajectory prediction with convolutional neural networks. Pattern Recognition. Elsevier, 2022. Dostupné z: doi:https://doi.org/10.1016/j.patcog.2021.108252

[9] GOLDHAMMER, Michael, Konrad DOLL, Ulrich BRUNSMANN, André GENSLER a Bernhard SICK. Pedestrian's Trajectory Forecast in Public Traffic with Artificial Neural Networks. 22nd International Conference on Pattern Recognition. 2014, , 4110-4115. Dostupné z: doi:10.1109/ICPR.2014.704

[10] MA, Yi, Eric Wai Ming LEE a Richard Kwok Kit YUEN. An Artificial Intelligence-Based Approach for Simulating Pedestrian Movement. IEEE Transactions on Intelligent Transportation Systems. 2016, 17(11). ISSN 1558-0016. Dostupné z: doi:10.1109/TITS.2016.2542843

[11] TORDEUX, Antoine, Mohcine CHRAIBI, Armin SEYFRIED a Andreas SCHADSCHNEIDER. Prediction of pedestrian dynamics in complex architectures with artificial neural networks. Journal of Intelligent Transportation Systems Technology Planning and Operations. 2020, 6(24). Dostupné z: doi:10.1080/15472450.2019.1621756

[12] CHEN, Yu Fan, Michael EVERETT, Miao LIU a Jonathan P. HOW. Socially Aware Motion Planning with Deep Reinforcement Learning. IEEE/RSJ International Conference on Intelligent Robots and Systems (IROS). 2017. Dostupné z: doi:10.1109/IROS.2017.8202312

[13] DAS, Pritikana, Manoranjan PARIDA a V. K. KATIYAR. Analysis of interrelationship between pedestrian flow parameters using artificial neural network. Journal of Modern Transportation. 2015, 35(6). Dostupné z: doi:10.1007/s40534-015-0088-9 
[14] THORNTON, Charles, Richard O'KONSKI, B. HARDEMAN a Daniel SWENSON. Pathfinder: An Agent-Based Egress Simulator. 2011. Dostupné z: doi:10.1007/978-1-4419-9725-8_94

[15] RONCHI, Enrico, Paul A. RENEKE a Richard PEACOCK. A Method for the Analysis of Behavioural Uncertainty in Evacuation Modelling. Fire Technology. 2014, (50), 1545-1571.

[16] LOVREGLIO, Ruggiero, Erica KULIGOWSKI, Steve GWYNNE a Karen BOYCE. A pre-evacuation database for use in egress simulations. Fire Safety Journal. 2019, 105, 107-128. ISSN 0379-7112. Dostupné z: doi://doi.org/10.1016/j.firesaf.2018.12.009 